\title{
SCREENING OF WILD Helianthus species FOR RESISTANCE TO HIGH VIRULENT Orobanche cumana Wallr., AFFECTING SUNFLOWER IN THE ROSTOV REGION OF THE RUSSIAN FEDERATION
}

Antonova, T.S. , Araslanova, N.M., Strelnikov, E.A., Ramazanova, S.A., Tchelustnikova, T.A., Guchetl, S.Z.

All Russia Research Institute of Oil Crops by the name of V.S. Pustovoit (VNIIMK), 350038, Filatov str. 17, Krasnodar, Russia

Received: November 15, 2011 Accepted: December 10, 2011

\section{SUMMARY}

During the last years in Rostov region of Russian Federation highly virulent biotypes of broomrape have propagated, affecting both hybrids of foreign breeding, and the native sunflower assortment, which used to be resistant earlier. Apart from that, the resistance of some known European sunflower types to broomrape races had disappeared, which testifies about the presence of the races $\mathrm{F}, \mathrm{G}, \mathrm{H}$ in the region at least. Consequently, the search of the sources of resistance is urgent.

14 samples of annual and 27 of perennial wild sunflower from the collection of Kuban experimental station VIR were tested for resistance to the most virulent broomrape population. From the annual species only $H$. petiolaris had weak degree of affection (1-3 tubercles/plant), while the other were affected to a high degree. The majority of perennial sunflower samples have shown the immunity.

Perennial wild species of the sunflower of the same name that were used earlier in the research of Ruso et al. (1996) as resistant species against the Spanish populations of broomrape, show resistance also to high virulent $O$. cumana, which had propagated in the Rostov region of the Russian Federation.

The immunity to broomrape of the studied wild perennial sunflower samples is not related to the absence of stimulating effect of root exudations on the seeds of the parasite. The immunity is more likely connected to physiologicalbiochemical features of cortex root cells.

Key words: Helianthus, wild species, resistance, broomrape, high virulent races

* Corresponding author: Phone: +(861)275-86-53, mobile: 89181888161 , Fax: + (861)254-27-80; e-mail: antonova-ts@mail.ru 


\section{INTRODUCTION}

In many countries where the sunflower is cultivated the obligate parasite broomrape (Orobanche cumana Wallr.), which affects the higher floral plants, is considered to be the one of the most dangerous factors in the production of this crop. During last 15 years the attempts of breeders of different countries to present genetic sources of sunflower hybrids broomrape resistance were followed by the occurrence of new virulent races, which quickly overcame all known genes of resistance (Fernandez-Martinez et al., 2008). Because of this situation, the majority of researches had become concentrated on the development and characteristics of new sources of genetic resistance to most virulent races and also on the genetic structure and variability of $O$. cumana populations and their evolution to develop long-term strategies to control this parasite.

In Russia O. cumana has a centenary history of parasitism on sunflower. In course of these years the sunflower had been under the risk of disappearance when its cultivation was not profitable because of the strong affection by broomrape. However, the problem was successfully solved by the development of resistant hybrids and by strict observance of scientifically based crop rotations in the former USSR.

So far as the seeds of broomrape have germinated in the presence of root exudations of both susceptible and resistant genotypes of sunflower. The cultivation of the resistant varieties and hybrids since the middle of 70's until the middle of 90's of the last century led to the destruction of the basic stocks of seeds of the parasite in the fields. Throughout the 90's it was even difficult to find and to collect the necessary quantity of the broomrape seeds to create the infectious backgrounds to test the breeding material's resistance to it. The problem did not arise until the beginning of the present century.

High profitability of production of sunflower seeds in Russian Federation during 90's had led to a disorder in crop rotations occurring everywhere, especially in Rostov region, where the sunflower was often returned to the former place in 1-3 years. As a result of such intensification of this crop seeds production in many areas of Rostov region the broomrape biotypes had appeared and propagated, they had quickly overcome the immunity of both native assortments of sunflower and foreign hybrids. It was also conduced by the usage of the hybrids of sunflower foreign breeding as a sowing material, which was susceptible to local populations of broomrape (such as Rigasol, Printasol, Cargill 207 and others). Thus the reproduction of seeds of the parasite was recommenced.

Vrânceanu et al. (1980) differentiated five races of a parasite from A to $\mathrm{E}$ on five hosts-differentiators, having the genes of resistance from $\mathrm{Or}_{1}$ to $\mathrm{Or}_{5}$. The designation of these races (except race A) did not coincide with the names of the races in USSR, where the letter B referred not to one single race, but to a so-called "complex of races $\mathrm{B}$ ". And the letter $\mathrm{C}$ designated high virulent biotype which appeared at the 
beginning of the 70's in Moldova on the border with Romania, which overcame the resistance of the cultivated assortment of that time to the complex of races B. The development of varieties and hybrids resistant to this biotype facilitated the destruction of stocks of seeds of a parasite in the fields of Russian Federation since the middle of 70's until the middle of 90's.

In Spain in 1995 the new race $\mathrm{F}$, which overtook all known genes of resistance from $\mathrm{Or}_{1}$ to $\mathrm{Or}_{5}$ (Alonso et al., 1996; Dominguez, 1996; Fernandez-Escobar et al., 2008) appeared and quickly propagated. The resistance to it was found in the germplasm of cultivated varieties, as well as of wild sunflower (Sukno et al., 1998; Fernandez-Martinez et al., 2000; Rodriguez-Ojeda et al., 2001). However, soon more virulent race (designated as race $\mathrm{G}$ ) was identified, affecting cultivated hybrids, resistant to race $\mathrm{F}$ (Molinero-Ruiz and Melero-Vara, 2005). The virulent races overcoming the gene of resistance Or $_{5}$ were also identified in Romania in 1996 (Pâcureanu et al., 2004, 2008), Bulgaria (Shindrova, 2006) and Turkey, where the new biotypes were marked as more virulent than in other countries (Kaya et al., 2004).

In the Rostov region of the Russian Federation, according to our investigation (Antonova et al., 2009, 2010), there are biotypes of broomrape that overcome the resistance of genes $\mathrm{Or}_{5}, \mathrm{Or}_{6}, \mathrm{Or}_{7}$, the mutual action of genes $\mathrm{Or}_{6} \mathrm{Or}_{7}$ and the resistance of hybrid combination $16 \times 25$, resistant to race G in Romania. However, it is not clear yet whether the Russian biotypes of broomrape are identical with the races F, G, H, found in Turkey and other countries. Moreover, some biotypes have higher virulence than the sample of seeds from Turkey, which consists of a mix of races $\mathrm{F}$, $\mathrm{G}, \mathrm{H}$.

Many researches from other countries had reported earlier on the resistance of some annual and perennial wild species of sunflower to different races of $O$. cumana (Ruso et al., 1996; Christov, 1996; Christov et al., 2009; Fernandez-Martinez et al., 2000; Terzić et al., 2010). It has been proved that the wild species of Helianthus are the main source of the genes that control the resistance to new virulent races of broomrape.

However, it is not known whether the wild species of sunflower are resistant to modern high-virulent biotypes of broomrape from the Rostov region. Owing to the nomenclature of the races of $O$. cumana in the Russian Federation, which is not yet in the conformity with the nomenclature in other countries, this question requires studying.

The purpose of our researches was to test annual and perennial species of wild sunflower from the germplasm collection of VIR Kuban experimental station for resistance to high-virulent biotypes of broomrape from Rostov region of Russian Federation. 


\section{MATERIALS AND METHODS}

40 samples of annual and perennial species of Helianthus from the germplasm collection of VIR Kuban experimental station were tested.

Annual species: $H$. annuus L. -5 samples of different years of introduction, $H$. petiolaris Nutt. subsp. petiolaris -3 samples, $H$. debilis Nutt. -3 samples, $H$. praecox Engleman \& Gray subsp. praecox, H. argophyllus Torr. \& Gray - 2 samples.

Perennial species: $H$. californicus DC., $H$. decapetalus L. -2 samples, $H$. divaricatus L., H. qlaucophyllus Smith., H. floridanus L., H. giganteus L. - 4 samples, H. qrosseserratus G. Martens - 3 samples, H. hirsutus Raf., H. laetiflorus Pers., H. maximiliani Schrad. - 3 samples, H. mollis Lam., H. multiflorus Hook. Fl. Bor. Am., H. nuttallii Torr. \& Gray subsp. nuttallii, H. nuttallii Torr. \& Gray subsp. parishii, H. occidentalis subsp. plantagineus (Torr. \& Gray) Heiser, H. salicifolius Dietr. - 3 samples, H. tuberosus L.

The resistance of annual sunflower species was estimated in the greenhouse. The seeds were planted by 15 pieces in rows, in the boxes with the capacity of 250 $\mathrm{kg}$ of soil and sand mix together with the $200 \mathrm{mg}$ of broomrape seeds for $1 \mathrm{~kg}$. Plants grew up within 45 days after the seedlings appeared, then they were dug out and the quantity of tubercles and seedlings of parasite were counted. The variety VNIIMK 8883 was used as the susceptible control.

To accelerate the germination of seeds of perennial samples of sunflower the procedures of the presowing processing, described by Ruso with co-authors (Ruso et al., 1996) were used. The germinated seeds were planted by 3 in the flowerpots with 5 litres volume, filled with a mix of soil and sand, together with the seeds of broomrape which were added as $200 \mathrm{mg}$ on $1 \mathrm{~kg}$ of soil mix. Plants of each sample of collection grew up in 10 pots within 4 months $\left(1^{\text {st }}\right.$ month-in greenhouse at the temperature $25-27^{\circ} \mathrm{C}$, then in natural open-air conditions from June until August, 2010) and were watered daily when the top layer of soil dried. The broomrape seeds of two populations were used: high virulent one-from Tatsinsky area of the Rostov region and less virulent one-from Yeysk area of Krasnodar region. The quantity of broomrape stems appearing on the soil surface was taken into account. Then the sunflower plants were dug out and the total quantity of tubercles and shoots of the parasite on their roots was calculated.

In order to define the ability of roots of perennial sunflower samples to stimulate the germination of seeds of $O$. cumana, the seeds were grown at the temperature of $25^{\circ} \mathrm{C}$ in the rolls of wet filter paper put vertically in a glass vessel with a small amount of water at the bottom. To create the moist chamber the vessel was covered with transparent film. The rolls were unwrapped when the roots of sunflower seedlings reached $3-5 \mathrm{~cm}$. The seeds of broomrape were placed on the roots and rolls were made up again. The further joint cultivation passed at the temperature $25-30^{\circ} \mathrm{C}$ and during the photoperiod of 16 hours. In 20 and 30 days the rolls 
were opened and the germination of seeds of a parasite was observed by means of stereoscopic microscope.

\section{RESULTS AND DISCUSSION}

The results of research of both broomrape populations show that the studied samples of annual sunflower are strongly affected by Tatsinsky broomrape from Rostov region. Only $H$. petiolaris had insignificant degree of affection (1-3 tubercles on one affected plant). However, plants of this species are completely resistant to broomrape from Yeysk area of Krasnodar region, so are the samples of $H$. debilis and H. praecox (Table 1). In researches of Terzić et al. (2010) it is shown that in Serbia these species show resistance to race $\mathrm{E}$ of $O$. cumana. That corresponds to our data as well. The broomrape from Yeysk district of Krasnodar region is less virulent, its virulence doesn't exceed that of race E. And some cultivated sunflower varieties and hybrids have resistance to it. At the same time, the presence of much more virulent populations of broomrape, which overcame the resistance of these annual species, doesn't allow the recommendation to use these species in crossbreeding with cultivated sunflower to improve the immunity.

Table 1: Reaction of 14 samples of annual wild Helianthus species to two populations of $O$. cumana from the South of the Russian Federation

\begin{tabular}{lccccc}
\hline \multirow{2}{*}{$\begin{array}{c}\text { Samples of wild } \\
\text { Helianthus } \\
\text { species }\end{array}$} & $\begin{array}{c}\text { Introduction, } \\
\text { number }^{\mathbf{a}}\end{array}$ & & \multicolumn{4}{c}{ O. cumana population } \\
\cline { 3 - 6 } & & \multicolumn{1}{c}{ Krasnodar region, Yeysk area } & Rostov region, Tatsinsky area \\
\cline { 3 - 6 } & Incidence ${ }^{\mathbf{b}},(\%)$ & DA $^{\mathbf{c}}$ & Incidence $^{\mathbf{b}},(\%)$ & DA $^{\mathbf{c}}$ \\
\hline H. annuus & 398940 & 26 & 2 & 100 & 57 \\
H. annuus & 407260 & 38 & 3 & 100 & 48 \\
H. annuus & 440524 & 31 & 5 & 100 & 76 \\
H. annuus & 441082 & 44 & 11 & 100 & 103 \\
H. annuus & 545580 & 41 & 7 & 100 & 97 \\
H. petiolaris & 440560 & 0 & 0 & 80 & 1 \\
H. petiolaris & 440612 & 0 & 0 & 92 & 2 \\
H. petiolaris & 503232 & 0 & 0 & 86 & 3 \\
H. debilis & 545666 & 0 & 0 & 73 & 38 \\
H. debilis & 560388 & 0 & 0 & 64 & 27 \\
H. debilis & 560395 & 27 & 3 & 100 & 23 \\
H. praecox & 560400 & 0 & 0 & 86 & 30 \\
H. argophyllus & 545664 & 33 & 4 & 100 & 57 \\
H. argophyllus & ARY Mosam- & 39 & 6 & 100 & 22 \\
& bik 1809 & & & & \\
\hline
\end{tabular}

${ }^{\mathrm{a}}$ Correspondence to number in collection of VIR Kuban experimental station

b Incidence: number of infected plants / total number of sunflower plants

${ }^{\mathrm{c}}$ Degree of attack: average number of broomrape per affected sunflower plant

Perennial samples of wild sunflower in majority have shown full resistance except insignificant affection of $H$. mollis and some analogs in the following species: 
H. giganteus, $H$. grosseserratus, $H$. maximiliani, $H$. salicifolius, $H$. multiflorus (Table 2). This insignificant affection of samples-analogs can be considered as a consequence of wild species heterogeneity and the possibility to show variability of their features, in particular, the resistance or the susceptibility, pointed out by Ruso et al. (1996).

Table 2: Reaction of 27 samples of perennial wild Helianthus species to two populations of $O$. cumana from the South of Russian Federation

\begin{tabular}{|c|c|c|c|c|c|}
\hline \multirow{3}{*}{$\begin{array}{c}\text { Samples of wild } \\
\text { Helianthus } \\
\text { species }\end{array}$} & \multirow{3}{*}{$\begin{array}{l}\text { Introduction, } \\
\text { number }^{\mathrm{a}}\end{array}$} & \multicolumn{4}{|c|}{ O. cumana population } \\
\hline & & \multicolumn{2}{|c|}{ Krasnodar region, Yeysk area } & \multicolumn{2}{|c|}{ Rostov region, Tatsinsky area } \\
\hline & & Incidence $^{\mathbf{b}}, \%$ & $\mathrm{DA}^{\mathrm{c}}$ & Incidence $^{\mathbf{b}}, \%$ & $\mathrm{DA}^{\mathrm{c}}$ \\
\hline H. floridanus & - & 0 & 0 & 0 & 0 \\
\hline H. decapetalus* & 440439 & 0 & 0 & 0 & 0 \\
\hline H. decapetalus & - & 0 & 0 & 0 & 0 \\
\hline H. divaricatus & 545674 & 0 & 0 & 0 & 0 \\
\hline H. hirsutus & 560389 & 0 & 0 & 0 & 0 \\
\hline H. mollis & 530453 & 0 & 0 & 100 & 1 \\
\hline H. laetiflorus* & 1886 & 0 & 0 & 0 & 0 \\
\hline H. tuberosus & 441026 & 0 & 0 & 0 & 0 \\
\hline H. californicus* & 530447 & 0 & 0 & 0 & 0 \\
\hline H. giganteus & 489253 & 0 & 0 & 0 & 0 \\
\hline H. giganteus* & - & 0 & 0 & 0 & 0 \\
\hline H. giganteus & - & 0 & 0 & 100 & 1 \\
\hline H. giganteus & 441029 & 0 & 0 & 0 & 0 \\
\hline H. grosseserratus & 545698 & 0 & 0 & 100 & 2 \\
\hline H. grosseserratus* & 545711 & 0 & 0 & 0 & 0 \\
\hline H. grosseserratus & - & 0 & 0 & 0 & 0 \\
\hline H. maximiliani & 440553 & 0 & 0 & 0 & 0 \\
\hline H. maximiliani & 2099 & 0 & 0 & 67 & 2 \\
\hline H. maximiliani & - & 0 & 0 & 0 & 0 \\
\hline H. nuttallii & - & 0 & 0 & 0 & 0 \\
\hline H. nuttallii & - & 0 & 0 & 0 & 0 \\
\hline H. salicifolius* & 440074 & 0 & 0 & 0 & 0 \\
\hline H. salicifolius & - & 0 & 0 & 0 & 0 \\
\hline H. salicifolius & - & 0 & 0 & 100 & 1 \\
\hline H. glaucophyllus & - & 0 & 0 & 0 & 0 \\
\hline H. multiflorus & - & 0 & 0 & 100 & 2 \\
\hline H. occidentalis* & 611801 & 0 & 0 & 0 & 0 \\
\hline
\end{tabular}

${ }^{a}$ Correspondence to number in the collection of VIR Kuban experimental station

${ }^{b}$ Incidence: number of infected plants / total number of sunflower plants

c Degree of attack: average number of broomrape per affected sunflower plant

* Samples are tested for their root exudation ability to cause germination of broomrape seeds

The majority of perennial species studied in our research had been tested earlier by Ruso et al. (1996) on their resistance to broomrape in Spain. Our data show 


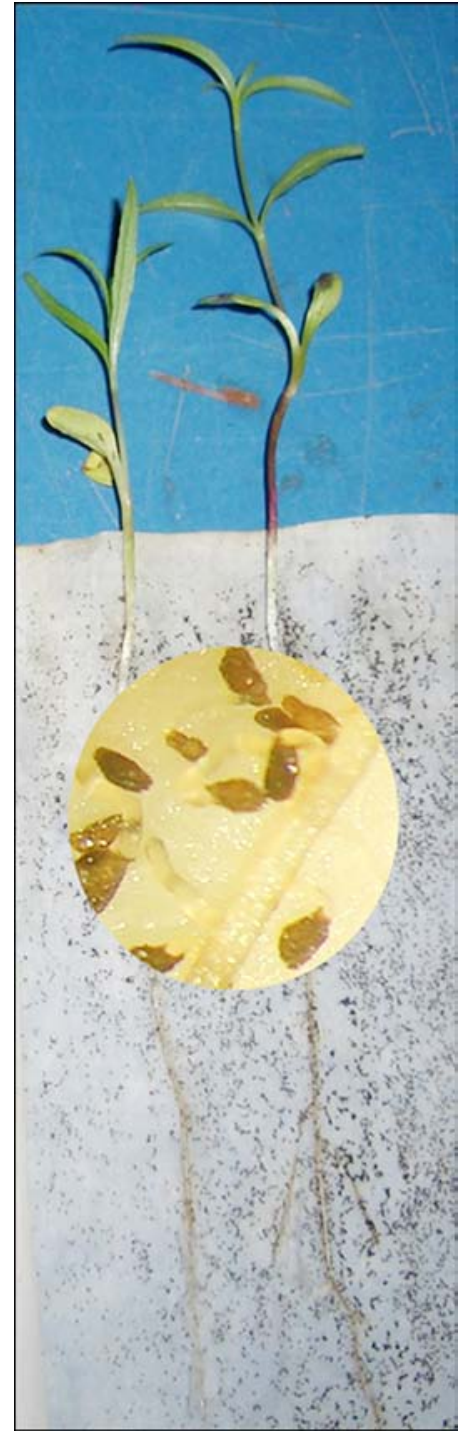

Figure 1: Plants of $H$. californicus in 20 days after germination with seeds of $O$. cumana germinated on their roots and on all area of a filter paper, increase: $\times 21$. that they are also resistant to high-virulent broomrape from Rostov region of Russian Federation.

Ruso et al. (1996), Fernandez-Martinez et al. (2000, 2008), Fernandez-Martinez and Ruso (1997) and Terzić et al. (2010) pointed out the resistance to broomrape from different countries of perennial species, $\mathrm{F}_{1}$ and cultivated sunflower. Sukno et al. (1998) showed that the cross ability, the resistance $F_{1}$ and backcross generations with different levels of ploidy, as well as the transference of resistance to broomrape to cultivated sunflower from wild species with different levels of ploidy are practically realizable. Therefore, it is necessary to develop experimental work in this direction in Russia to put the breeding programs for development of the sunflower assortment resistant to new races of $O$. cumana.

Potentially the sunflower immunity to broomrape can manifest itself through the absence of the root ability to stimulate the germination of parasite seeds. Therefore, it was the matter of interest to find out whether the broomrape seeds from the studied populations germinate in the presence of roots of perennial samples designated by the sign $(*)$ in the Table 2 . Seeds of both populations of broomrape germinated actively both on roots and on the whole surface of the filter paper which had become soaked with root exudations of sunflower plants. The threadlike root of germinated broomrape seeds started to penetrate into sunflower root, however, the tubercle did not develop (Figure 1). The haustorial cells of a parasite, penetrated into the root of sunflower, perished in the external layers of cortex parenchyma and differed from surrounding cells of a host by their light-brown color. That indicates that the immunity of the studied wild perennial samples of sunflower to broomrape is not related to the absence of the stimulating effect of host root exudations on the seeds of the parasite. The immunity is more likely connected with physiological-biochemical features of cortex cells of root. 


\section{CONCLUSION}

Thus, the most virulent biotypes of $O$. cumana from Rostov region of the Russian Federation do not overcome the immunity of the studied sunflower perennial species. The seeds of that broomrape germinate in the presence of roots of the studied samples: H. decapetalus, H. laetiflorus, H. californicus, H. giganteus, $H$. grosseserratus, $H$. salicifolius, $H$. occidentalis. The threadlike root of germinated broomrape seeds begin to penetrate into the root of these species, but their haustorial cells perish rapidly in the external layers of the cortex parenchyma.

\section{ACKNOWLEDGEMENTS}

Authors express their gratitude to Dr. Gavrilova V.A. and to the administration of Kuban experimental station VIR for cooperation and the given seeds of wild samples of sunflower, and also to Nagaitseva A.O. for the proper translation of the manuscript to English.

\section{REFERENCES}

Alonso, L.C., 1996. New highly virulent sunflower broomrape (Orobanche cumana Wallr.) phenotypes in Spain. Advances in parasitic plant research. $6^{\text {th }}$ International Parasitic Weed Symposium, April 16-18, 1996. Cordoba, Spain.

Antonova, T.S., Araslanova, N.M., Guchetl, S.Z., Ramazanova, S.A., Chelyustnikova, T.A., 2010. Affection of European sunflower differentials by broomrape from Rostov region of the Russian Federation. In: Proceedings of the International Symposium "Sunflower Breeding on Resistance to Diseases"-Krasnodar, Russia, June 23-24, 2010. Pp. 107-111.

[Electronic resource]-URL: http://www.vniimk.ru/site/res/symposium/International_Symposium_Sunflower_Breeding_On_Resistance_To_Diseases_Proceedings.pdf (Last date of the reference: $0 \overline{3} \cdot 10.2011$. .)

Antonova, T.S., Araslanova, N.M., Guchetl, S.Z., Ramazanova, S.A., Chelyustnikova, T.A., 2009. Spreading and virulence of broomrape (Orobanche cumana Wall.) on sunflower in Rostov region. Oil Crops, 2009. 1(140): 31-37. (In Russian)

Christov, M., 1996. Characterization of wild Helianthus species as sources of new features for sunflower breeding. In: P.D.S. Caligari \& D.J.N. Hind (eds). Compositae: Biology \& Utilization. Proceedings of the International Compositae Conference, Kew, 1994. (D.J.N. Hind, Editor-in-Chief), Vol. 2: 547-570. Royal Botanic Gardens, Kew.

Christov, M., Batchvarova, R., Christova-Cherbadzi, M., 2009. Wild species of Helianthus L.sources of resistance to the parasite Orobanche cumana Wallr. Helia 32(51): 65-74.

Dominguez, J., 1996. R-41 a sunflower restorer inbred line carrying two genes for resistance against a highly virulent Spanish population of Orobanche cernua. Plant Breed. 115: 203-204.

Fernandez-Escobar, J., Rodriguez-Ojeda, M.I., Alonso, L.C., 2008. Distribution and dissemination of sunflower broomrape (Orobanche cumana Wallr.) rase F in Southern Spain. Proc. $17^{\text {th }}$ International Sunflower Conference. Cordoba, Spain. Vol.1: 231-236.

Fernandez-Martinez, J.M., Dominguez, J., Perez-Vich, B. and Velasco, L., 2008. Update on breeding for resistance to sunflower broomrape Helia 31: 73-84.

Fernandez-Martinez, J. and Ruso, J., 1997. Evaluation of wild Helianthus species. FAO Progress Report 1995-1996, Giessen, Germany, 1997, pp. 43-46.

Fernandez-Martinez, J., Melero-Vara, M.J., Minoz-Ruz, J., Ruso, J. and Dominguez, J., 2000. Selection of wild and cultivated sunflower for resistance to a new broomrape race that overcomes resistance of the Or5 gene. Crop Science 40(2): 550-555.

Kaya, Y., Evci, G., Pekcan, V. and Gucer, T., 2004. Determining new broomrape infested areas, resistant lines and hybrids in Trakya region of Turkey. Helia 27(40): 211-218. 
Molinero-Ruiz, M.L. and Melero-Vara, J.M., 2005. Virulence and aggressiveness of sunflower broomrape (Orobanche cumana) populations overcoming the Or5 gene. In: G.J. Seiler, (ed), Proc. Int. Sunflower Conf., Fargo, ND, USA. Pp. 165-169.

Pãcureanu-Joita, M, Raranciuc, S., Procopovici, E., Sava, E., Nastase, D., 2008. The impact of the new races of broomrape (Orobanche cumana Wallr.) parasite in sunflower crop in Romania. Proc. $17^{\text {th }}$ International Sunflower Conference. Cordoba, Spain. V.1.-?: 225230.

Rodriguez-Ojeda, M.I., Fernandes-Escobar, J. and Alonso, L.C., 2001. Sunflower inbred line (KI-374) carrying two recessive genes for resistance against a highly virulent Spanish population of Orobanche cernua Loefl./O. cumana Wallr. Race "F". In: Proc. $7^{\text {th }}$ Int. Parasitic Weed Symposium, 5-8 June. 2001. Nantes, France. Pp. 2008-2011.

Ruso, J., Sukno, S. Dominguez-Gimenez, J., Melero-Vara, J.M., Fernandez-Martinez, J., 1996. Screening of wild Helianthus species and derived lines for resistance to several populations of Orobanche cernua. Plant Disease pp. 1165-1169.

Shindrova, P., 2006. Broomrape (Orobanche cumana Wallr.) in Bulgaria - distribution and race composition. Helia 29(44): 111-120.

Sukno, S., Jan, C.C., Melero-Vara, J.M. and Fernandez-Martinez, J.M., 1998. Reproductive behavior and broomrape resistance in interspecific hybrid of sunflower. Plant Breeding 117: 279-285.

Terzić, S., Dedić, B., Atlagić, J., Jocić, S. and Tančić, S., 2010. Screening wild sunflower species and $F_{1}$ interspecific hybrids for resistance to broomrape. Helia 33(53): 25-30.

Vrânceanu, A.V., Tudor, V.A., Stoenescu, F.M., Pirvu, N., 1980. Virulence groups of Orobanche cumana Wallr. Differential hosts and resistance sources and genes in sunflower. In: Proc. $9^{\text {th }}$ Int. Sunflower Conf. Torremolinos, Spain, 8-13 July 1980. Int. Sunflower Assoc., Paris, France. I: 74-80. 
